\title{
Stakeholders, as a Bridge Between Business Ethics and Corporate Social Responsibility
}

http://doi.org/10.21272/bel.5(4).68-75.2021

Andra Modreanu, ORCID: https://orcid.org/0000-0002-6476-288

PhD Student, The Bucharest University of Economic Studies, Bucharest, Romania

Gabriela Andrișan, ORCID: https://orcid.org/0000-0002-1815-9090

PhD Student, The Bucharest University of Economic Studies, Bucharest, Romania

\section{Abstract}

This paper summarizes the arguments and counterarguments within the scientific discussion on the issue of stakeholders, the drivers of business ethics and corporate social responsibility for companies nowadays. The main purpose of the research is to comprehend how integrating corporate social responsibility in the core of business may contribute to the creation of a positive organization image among stakeholders. Systematization literary sources and approaches for establishing ethical business indicate that integrating corporate social responsibility in the business strategy may ethically influence stakeholders' perception. The relevance of the decision of this scientific problem is that companies worldwide are facing a challenging period as the interests, expectations and needs of individuals are changing. Firms should embrace and adapt to the new reality to survive and function properly. For instance, besides economic objectives, organizations should strive to achieve social goals. Hence, companies should act based on fairness, responsibility, honesty, equity and morality. Investigation of the topic stakeholders, the drivers of business ethics and corporate social responsibility for companies nowadays in the paper is carried out in the following logical sequence: firstly, the theoretical concepts have been defined (ethics, business ethics, stakeholder theory, corporate social responsibility). Then the interdependency between business ethics and corporate social responsibility has been presented briefly. The methodological research was based on a quantitative method: the investigation and analysis of secondary data from 2016-2021. The paper presents the results of an empirical study focused on identifying how companies might create and maintain relationships with parties of interest in a responsible manner, which showed that in the initial phase of the process, corporate social responsibility should be integrated into the core of the business. The research empirically confirms and theoretically proves that an organization that develops positive relationships with its internal and external environment may benefit from credibility among stakeholders and a positive company image. The results of the research can be useful for practitioners or researchers interested in the responsible management of businesses.

Keywords: Business Environment, Company Image, Ethically Behavior, External Relationships, Internal Relationships.

JEL Classification: M14, I31, D64.

Cite as: Modreanu, A., Andrișan, G. (2021). Stakeholders, as a Bridge Between Business Ethics and Corporate Social Responsibility. Business Ethics and Leadership, 5(4), 68-75. http://doi.org/10.21272/bel.5(4).68-75.2021.

Received: 01 November 2021

Accepted: 12 December 2021

Published: 30 December 2021

Copyright: (C) 2021 by the author. Licensee Sumy State University, Ukraine. This article is an open access article distributed under the terms and conditions of the Creative Commons Attribution (CC BY) license (https://creativecommons.org/licenses/by/4.0/).

\section{Introduction}

During the last decades, the terms of business ethics and corporate social responsibility (CSR) have benefited from growing attention among researchers and practitioners due to their recognized contribution to building a responsible business environment (Toma, 2006; Toma, 2008; Toma et al., 2011a; Toma \& Hudea, 2012; Rossi et al., 2021). Companies worldwide face a challenging period as individuals' interests, expectations, and needs are changing (De Silva et al., 2021). Firms should embrace and adapt to the new reality to survive and function properly. For instance, besides economic objectives, business organizations should strive to achieve social objectives (Toma \& Marinescu, 2012). Hence, companies should act based on values such as fairness, responsibility, honesty, equity and morality. 
Even though more and more companies have become aware of the importance of integrating business ethics and CSR in their strategy, there are yet to present some negative examples of large-scale violations, with meaningful results on a global scale (O'Connor et al., 2020). Fortunately, this type of organizational behavior is sanctioned by the authorities and by stakeholders. Legitimate parties of interest represent an essential component associated with successful firms (Devalle et al., 2021). Therefore, an increasing number of firms put effort into building and maintaining strong relationships with their vital stakeholders. Several studies sustain, that stakeholders, especially consumers, have become more preoccupied by ethical and conscious matters (Hassan \& Rahman, 2021). The emerging queries considering the former affirmation are as follows: what do ethics mean, and the actions companies can take to be perceived by stakeholders as ethically?

This study aims to address the above questions by outlining what each ascending concept represents and why these should be accommodated in the core structure of firms. Furthermore, a model based on CSR principles has been developed to understand better the relationships formed between a company and its internal and external environment and how these connections may influence stakeholders' perception of the firm. This paper is structured as follows. The upcoming section presents the literature review (2nd section), divided into three parts: defining ethics and business ethics, stakeholders considered as the drivers of business ethics for the current business environment and the interdependency between business ethics and corporate social responsibility. Subsequently, the research methodology is detailed (3rd section). The fourth section presents the results of the study (4th section), followed by the closing section, respectively, the conclu sions.

\section{Literature Review}

1. Defining Ethics and Business Ethics. First, the concept of ethics is most often associated with an individual (when referring to someone's morality, attitude or characteristics) or firms (when concerning with the set of moral rules and norms that aim to control the behavior of economic agents and their economic activity at individual and collective level) (Lillie, 1955). Nowadays, the latest represents a topic of interest for researchers and practitioners of the academic and business environment (Imhanzenobe, 2021). Even though the term "ethics" has several definitions, a globally accepted definition does not yet exist (Duncan, 2021). For instance, ethics can be characterized as the deliberate reflection on qualities and standards: their substance and changes, and their significance, avocation, and assurance (Lewis, 1985). Or it may be perceived as a good or bad behavior with individually and/or collectively consequences (Brennan et al., 2021).

Therefore, neither business ethics represent a specific domain in which ethical matters are expected to be applied. The point of start for business ethics investigation is represented by the 1950s, which marked the laborers struggle to benefit their rights (Mladenovic et al., 2019). Nowadays, due to globalization, ethics in the organizational context involves the progressive incorporation of morality and social obligation assumptions (Imhanzenobe, 2021). Bussines ethics can be defined as a social arrangement, based on encompassed shared values; techniques for moral investigation; distinctive and personalized policies regarding employees and business activity overall, based on honesty, equality, integrity and equity, developed to obtain economic objectives by identifying and capitalizing the market requirements and opportunities (van Luijk, 1997). Therefore, ethics can be explained as the moral compass, the given directions that one (individuals, companies, or institutions) should follow or create based on certain principles, and the activities and decision made and meant to build and consolidate strong relationships (Klopotan et al., 2020).

2. Stakeholders, the Drivers of Business Ethics. Stakeholder theory illustrates the necessity of businesses nowadays. There is a pressuring need for comprehension regarding the managing approaches companies should follow, considering several dimensions such as ethics, responsibility, sustainability, and value creation to obtain economic objectives (Harrison et al., 2019). The term "stakeholder" has been presented as the ones (individuals or others) that can be affected by an organization's activity (Freeman et al., 2010). Furthermore, the stakeholder evaluation implies that a manager is required to consider all the parties who will be affected or who affect an important decision (Fryzel, 2011). An economic entity's environment represents the combination of two factors, namely the internal and external extent. The internal environment includes the relationships between workers and the managers, departments/compartments/services/ company offices, and the leadership approaches.

However, the external environment of a firm includes the microenvironment (for instance, suppliers, clients, competitors, public organizations, service providers), and macro environment (for example, the demographic, economic, legislative, technological, cultural, natural, and public environment) (Toma, 2013). Several typologies of stakeholders have been developed, starting from understanding an organization's environment. The most often referenced classification of these parties of interest comprises the following dimensions: internal and 
external. Internal stakeholders encompass: "employees, shareholders and managers/owners" (Voiculescu \& Neagu, 2016: 114). Additionally, external stakeholders incorporate "suppliers, business partners, customers, markets, local communities, non-governmental organizations and associations, national and international institutions and governments" (Voiculescu \& Neagu, 2016: 115) (Figure 1).

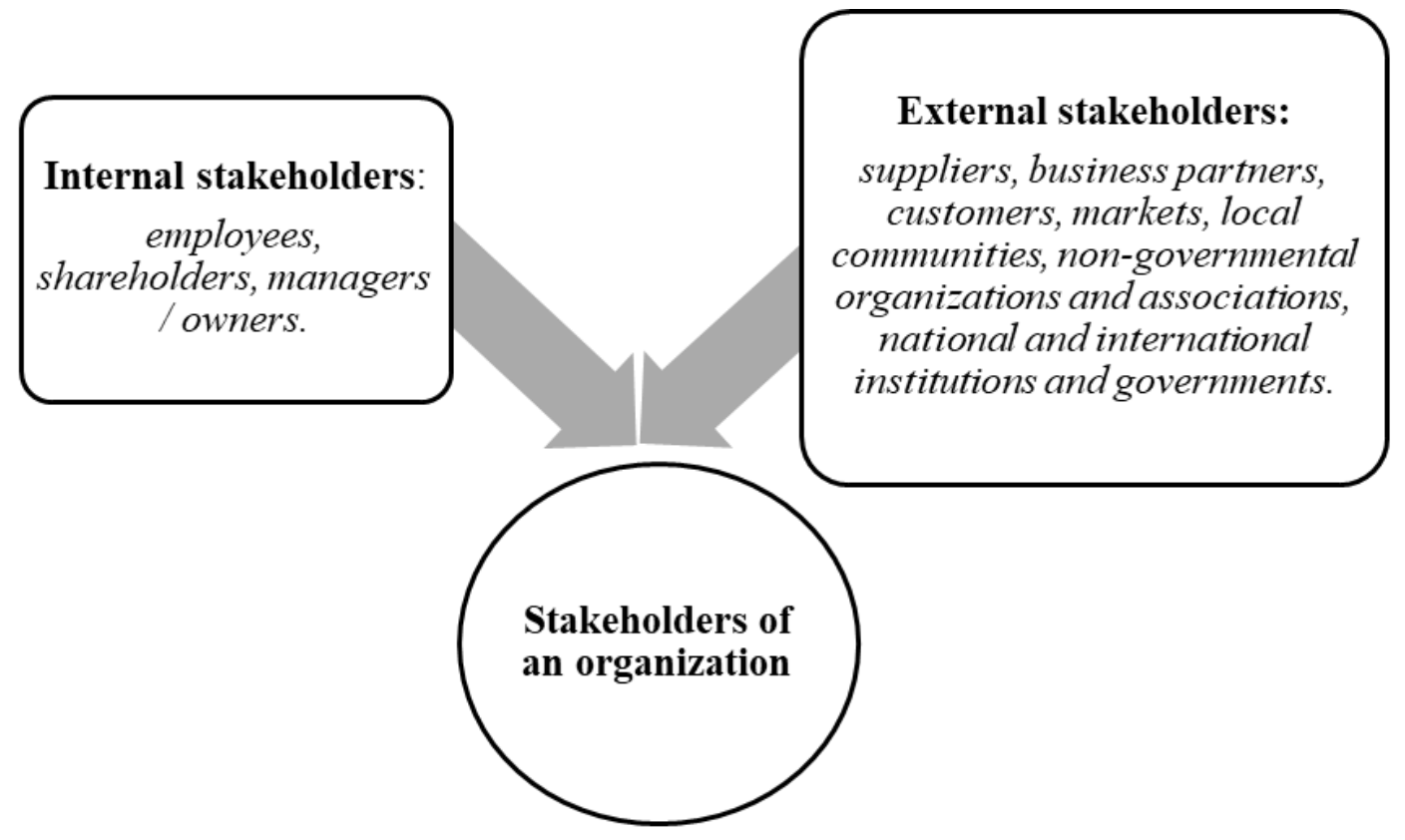

Figure 1. The Stakeholders of a Company

Source: Voiculescu and Neagu, 2016

The business represents a set of value-creating relationships among groups that have a legitimate interest in the actions and results of the economic entity and upon whom the firm depends on achieving its goals (Harrison et al., 2019: 3). Therefore, these parties of interest may be perceived as important factors that ensure a firm's functionality. Stakeholders supply valuable means for economic entities (Freeman \& McVea, 2001). Consequently, organizations strive to build and maintain long-lasting relationships with their legitimate parties of interests (Carroll, 2004). Beneficial connections are based, among others, on expectations that need to be met and mutual ethical behavior (Brennan et al., 2021). The current business environment acknowledges the importance of doing well by doing right mindset (Eabrasu, 2012). However, the issue, so far, remains the uncertainty regarding the methods or principles that can be used to create valuable relationships between an organization and its legitimate stakeholders (Rajablu et al., 2017). A firm that incorporates ethically thinking in the process of decision making, business strategy and core values might benefit from credibility among stakeholders (Langtry, 1994). Nevertheless, how can a company become ethical, or which steps should a firm follow to be perceived as ethical by stakeholders?

3. Business Ethics and CSR. Business ethics have been linked with various other terms. For instance, CSR has received growing attention among practitioners and researchers (Halkos \& Nomikos, 2021). More and more companies included CSR practices in their business strategy, having a clearly defined scope behind them to develop mutually beneficial relationships with legitimate parties of interest (Lokuwaduge \& De Silva, 2019). The conceptual framework of CSR is known as Caroll's pyramid, and it includes four types of responsibility as follows: "economical, legal, ethical and philanthropic" (Carroll \& Beiler, 1975: 593) (Fig. 1). The first responsibility of a company refers to profitability. To survive, firms need to earn more than they must spend to sustain their business activity. The following two responsibilities reveal how organizations should achieve profits, namely complying with existing laws and regulations and in an ethical manner (decisions and actions taken should be based on principles such as fairness, consideration, responsibility, and honesty). 


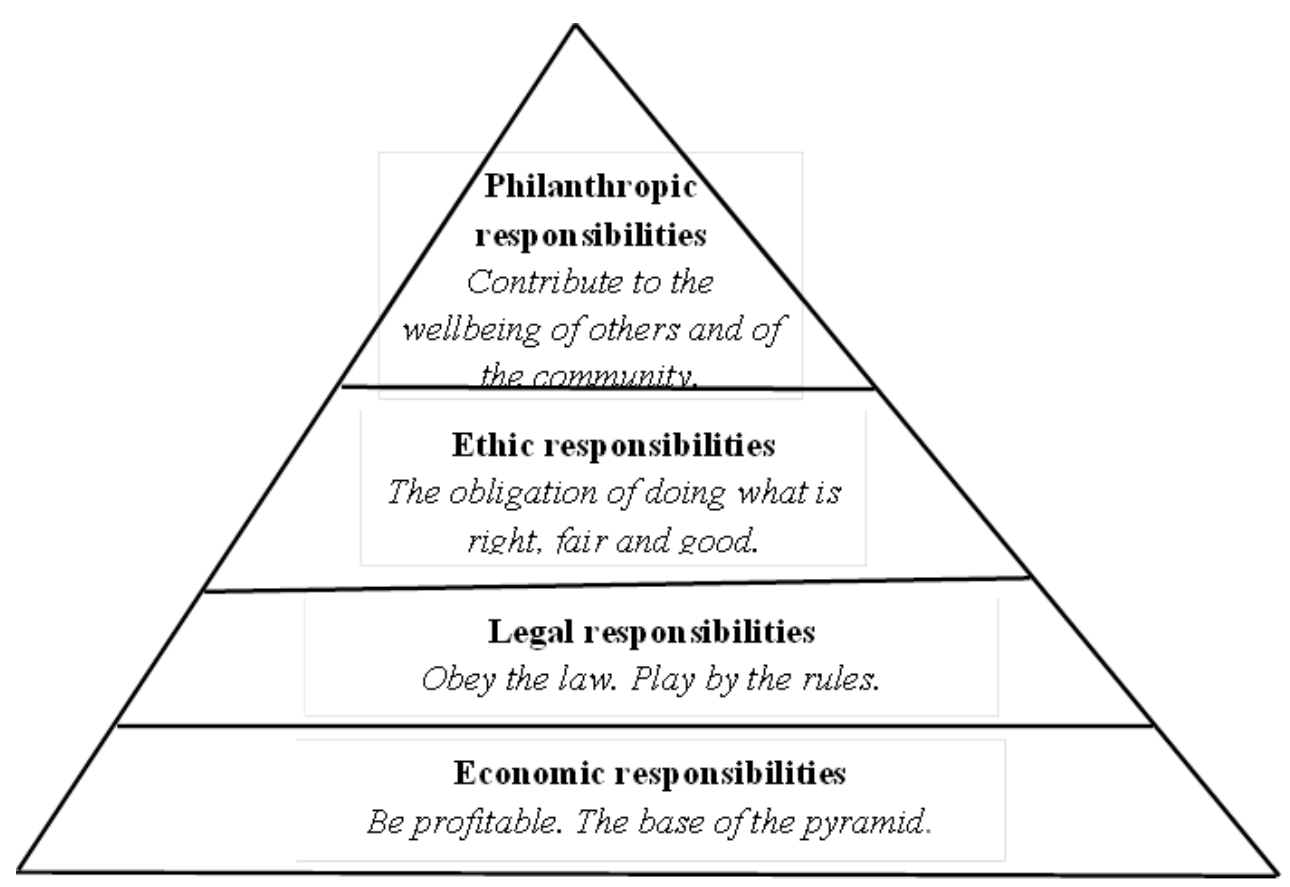

Figure 2. The Pyramid of Corporate Social Responsibility

Source: Carroll \& Beiler, 1975

Subsequently, the following responsibility concentrates on fulfilling the necessities of the community, environment, and society. Hence, CSR can be defined as a useful tool that organizations can use to build, in a responsible manner, a strong relationship with legitimate parties of interest (Feder \& Weißenberger, 2018). As a multidimensional concept, it aims to efficiently balance the interests of the business organization and its stakeholders (Toma et al., 2011b; Imbrișcă \& Toma, 2020). CSR may lead to social entrepreneurship, and therefore, contribute to the improvement of the quality of life (Zainea et al., 2020).

Corporate social responsibility and business ethics can be perceived as "interdependent" terms (Klopotan et al., 2020: 3). Ethics represents a significant component of CSR (Eabrasu, 2012). Hence, a company perceived as ethical by individuals can or cannot be considered an organization based on corporate social responsibility practices (CSR implies the existence of four types of responsibilities that economic entities should consider, the ethical one). Therefore, a company that is perceived as socially responsible is, also ethical.

\section{Methodology and Research Methods}

The present study was conducted following a quantitative approach, namely investigating and analyzing relevant secondary data for the chosen topic (scientific articles and existing books relevant to the subject). Starting from the established objective, respectively, understanding how integrating CSR in the core of business represents a possible solution to address the need for clarification regarding the actions companies can take to be perceived by stakeholders as ethically, a model has been developed in this scope. Therefore, several theoretical concepts have been used in this process (business ethics, stakeholder theory, the company's environment, and corporate social responsibility). As a practice identified in the existing literature, the analysis began with the presentation and understanding of the utilized terms that have been later on amalgamated in contemplation of achieving the stated goals of the research. This perspective regarding the development of the structure is complementary with other conducted studies such as Klopotan, Aleksić, and Vinković (2020) and Rossi, Festa, Chouaibi, S., and Fait.

\section{Results}

In the organizational context, the stakeholders represent the common ground for CSR and business ethics. Both concepts benefit from growing attention due to the possible contribution these can have in establishing the wellbeing in the relationships with legitimate parties of interest. Certainly, this is not the only reason (for instance, corporate social responsibility and ethics have been frequently associated with individuals' personal traits from top management positions). Still, it may be perceived as one of the most important drivers for motivating firms to integrate CSR or business ethics into their strategy. Due to the current business environment, creating beneficial and mutual connections between firms and their stakeholders is necessary. Results outline the utility of CSR and business ethics concepts in companies' strategy. Hence, these might 
serve as possible solutions to address the need for clarification regarding the actions companies can take to be perceived by stakeholders as ethically. Hence, a model has been developed in this scope, illustrating the corporate social responsibility process that organizations can follow to benefit from a positive image (responsible firm, implicitly ethically) among stakeholders (Fig. 3).

Based on a company's environment, two types of relationships can be formed, respectively internal and external. Internal connections represent the foundation of an organization. The mindset, actions, and decisions made within a firm should consider responsibility, wellbeing, fairness, and honesty. This ideal organizational culture should start as the top management team, owners, or shareholders implicated in the business activity. Being empowered, the leadership team can share and be implemented in their company values and beliefs based on CSR practices. These values and ideas can be passed to employees or used when recruiting workers to find individuals who are driven or, at least, familiar with such concepts. If the formed core of the firm has a common vision based on CSR, then the relationships built within the organization will be stronger and positive internal behavior will be developed. The latest will influence the external behavior representing the results of the connections established between the external environment (micro and macro environments) and the firm. Based on how a company interacts with its external and internal environment, the organization's image is developed and perceived by stakeholders (legitimate or not). Consequently, if an economic entity has incorporated terms such as CSR or business ethics in its strategy, then there is a high possibility that parties of interest will engage with the organization.

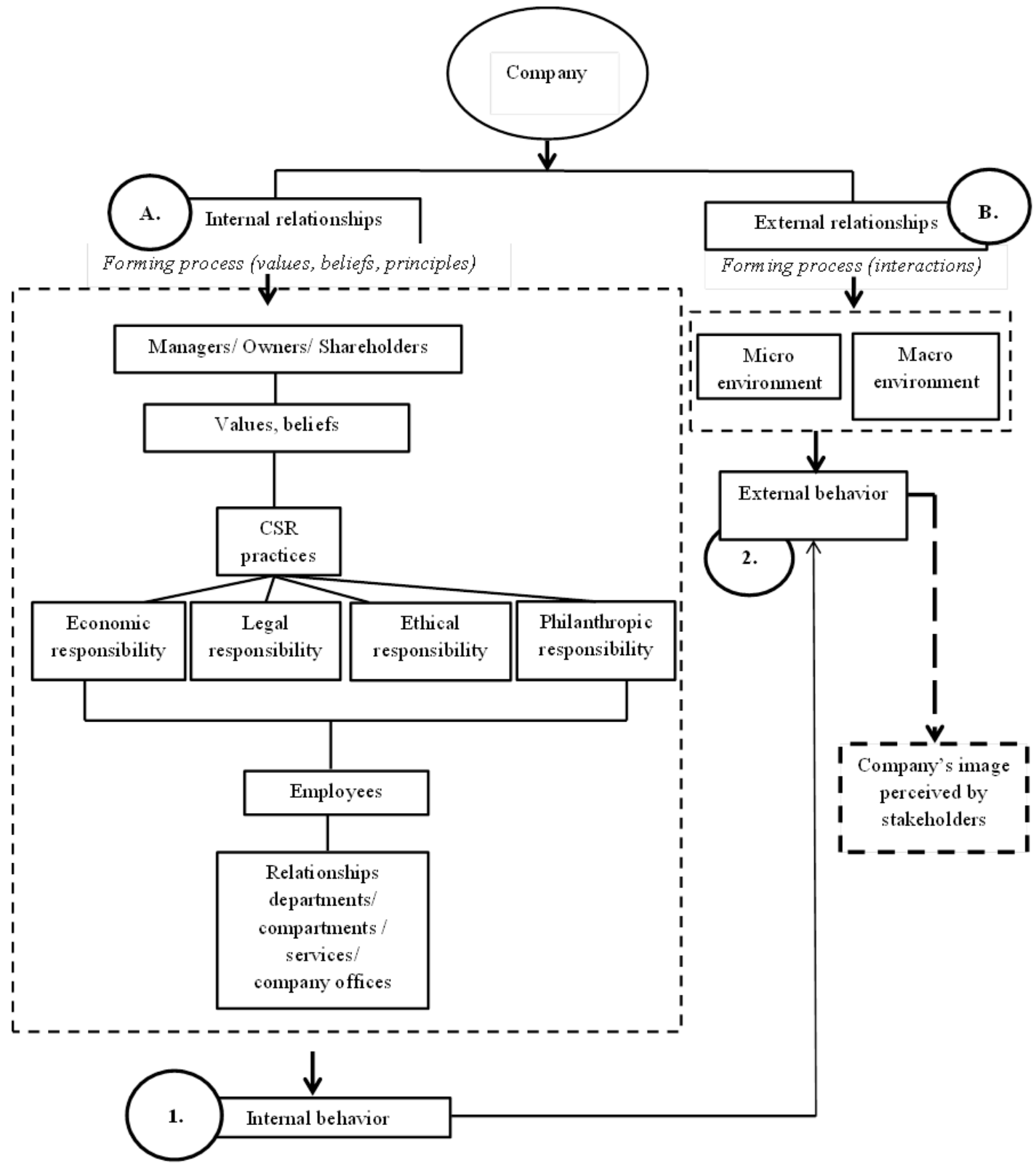

Figure 3. Building a Positive Image for Companies Based on CSR

Source: Author's own contribution based on literature review analysis 


\section{Conclusions}

Nowadays, several companies have begun to change their way of doing business by endorsing corporate social responsibility practices and business ethics approaches due to the pressuring expectations of stakeholders. Firms can no longer operate properly, focusing only on achieving economic objectives. Therefore, for the current business environment integrating the social component in business strategy has become necessary. Considering the variety of economic agents and available products and services, organizations need to step up and strive for creating long-lasting relationships with legitimate parties of interests. Corporate social responsibility and business ethics represent the foundation for companies to operate. Being perceived as an honest and fair player in the market will contribute significantly to the performance of an organization. Considering Maslow's pyramid, the necessities of individuals can be grouped into five categories, respectively physiological, safety, love and belonging, esteem, and self-actualization. The first level is based on the requirements of the standard functionality of the human body. Therefore, this stage incorporates necessities such as proper alimentation and relaxation. The physiological need is exploited, hence, satisfied, for instance, by commercialized products in this scope. The following component of the pyramid refers to security. This necessity may be fulfilled, also, by the acquisition of products from companies (for instance, a house).

On the other hand, the love, and a belonging level mark the transition to group affiliation. Firms also manage to satisfy this need (for instance, through the social media platforms created to eliminate distance and unify individuals). The fourth category emphasizes on the concepts of confidence and validation, while the last level exploits the potential. Organizations manage to cover even these needs by commercializing products or services (for instance, therapy to overcome a particularly traumatic event may be perceived as a service created for such circumstances). Thus, nowadays, companies can capitalize on all these opportunities from necessities. Corporate social responsibility and business ethics appeared as a need of self-actualization and self-esteem. These concepts are related to the individual and society simultaneously. Hence, firms that can improve their business activity by considering these principles may attract and build relationships based on the higher levels of the pyramid. Consequently, these connections which are formed on a stronger base may become, also, longlasting and long-term beneficial for both parties, respectively individuals and organizations.

This study outlines that responsible building business is not a straightforward process. It requires a significant effort, and individuals in top management positions have to ensure that they have the necessary tools to implement such practices. Certainly, a company that operates on values and beliefs based on responsibility, morality, equity, honesty and fairness would survive, prosper and grow. As individuals, a firms' functionality relays on the relationships they manage to build and maintain. The outcome of this study concurred with another theoretical approach on business ethics, stakeholder theory, and corporate social responsibility, such as Klopotan, Aleksić, and Vinković (2020). Moreover, this article proposed a model that illustrates how CSR can be integrated into the core of a business to create a positive image for the organization (responsible firm, implicitly ethically) among stakeholders. The scope of this paper is to sustain the importance of business ethics and corporate social responsibility concepts in managing relationships with legitimate parties of interest. The proposed model may be further analyzed and improved by other researchers to clarify why responsible business represents an important part of future business and the expected management approach.

Author Contributions: Conceptualization: Andra Modreanu; data curation: Andra Modreanu; formal analysis: Andra Modreanu; investigation: Andra Modreanu; methodology: Andra Modreanu; project administration: Andra Modreanu; resources: Andra Modreanu and Gabriela Andrișan; software: Andra Modreanu; supervision: Andra Modreanu; validation: Andra Modreanu; visualization: Andra Modreanu; writing - original draft: Andra Modreanu; writing - review \& editing: Andra Modreanu and Gabriela Andrișan.

Funding. There is no funding for this research.

\section{References}

1. Brennan, J., English, W., Hasnas, J., \& Jaworski, P. (2021). Business Ethics for Better Behavior. Oxford: Oxford University Press. 288 p. Available at: [Link]

2. Carroll, A.B. (2004). Managing ethically with global stakeholders: A present and future challenge. Academy of Management Perspectives, 18(2). [Google Scholar] [CrossRef]

3. Carroll, A.B., \& Beiler, G.W. (1975). Landmarks in the Evolution of the Social Audit. The Academy of Management Journal, 18(3), 589-599. [Google Scholar] [CrossRef] 
4. De Silva, M., Gokhberg, L., Meissner, D., \& Russo, M. (2021). Addressing societal challenges through the simultaneous generation of social and business values: A conceptual framework for science-based cocreation. Technovation Journal, 104(Ahead of print). [CrossRef]

5. Devalle, A., Gromis di Trana, M., Fiandrino, S., \& Vrontis, D. (2021). Integrated thinking rolls! Stakeholder engagement actions translate integrated thinking into practice. Meditari Accountancy Research Journal, 29(4), 943-965. [Google Scholar] [CrossRef]

6. Duncan, S. (2021). Ethical Business Book. A practical, non-preachy guide to business sustainability (1st ed.). London: LID Publishing. 182 p. Available at: [Link]

7. Eabrasu, M. (2012). A moral pluralist perspective on corporate social responsibility: From good to controversial practices. Journal of Business Ethics, 110(4), 429-439. [Google Scholar] [CrossRef]

8. Feder, M., \& Weißenberger, B.E. (2018). Understanding the behavioral gap: Why would managers (not) engage in CSR-related activities? Journal of Management Control, 29(3), 95-126. [Google Scholar] [CrossRef]

9. Freeman, E., Harisson, J.S., Wicks, A.C., \& De Colle, S. (2010). Stakeholder theory. The state of art. Cambridge: Cambridge University of Press. [Google Scholar]

10.Freeman, R.E., \& McVea, J. (2001). A Stakeholder Approach to Strategic Management. SSRN Electronic Journal. [Google Scholar] [CrossRef]

11.Fryzel, B. (2011). Building Stakeholder Relation and CSR. A sensemaking perspective. Hampshire: Palgrave Macmillan. 225 p. [Google Scholar]

12.Halkos, G., \& Nomikos, S. (2021). Corporate social responsibility: Trends in global reporting initiative standards. Economic Analysis and Policy Journal, 69, 106-117. [Google Scholar] [CrossRef]

13.Harrison, J.S., Barney, J.B., Freeman, E., \& Phillips, R.A. (2019). Stakeholder theory. Cambridge: Cambridge University Press. Available at: [Link]

14.Hassan, S., \& Rahman, Z. (2021). The evolving passage of consumer ethics research: a systematic literature review. International Journal of Emerging Markets, ahead-of-print (ahead-of-print). [Google Scholar] [CrossRef]

15.Klopotan, I., Aleksić, A., \& Vinković, N. (2020). Do Business Ethics and Ethical Decision Making Still Matter: Perspective of Different. Business Systems Research Journal, 11(1), 31-43. [Google Scholar] [CrossRef]

16.Imbrișcă, C. \& Toma, S.-G. (2020). Social responsibility, a key dimension in developing a sustainable higher education institution: The case of students' motivation. Amfiteatru Economic, 22(54), 447-461. [Google Scholar] [CrossRef]

17.Imhanzenobe, J. (2021). Impact of globalization on work ethics: A review of existing literature. Journal of Economics and International Finance, 13(3), 127-135. [Google Scholar] [CrossRef]

18.Langtry, B. (1994). Stakeholders and the Moral Responsibilities of Business. Business Ethics Quarterly, 4(4), 431-443. [Google Scholar] [CrossRef]

19.Lewis, P. (1985). Defining 'business ethics': Like nailing jello to a wall. Journal of Business Ethics, 4 , 377-383. [Google Scholar] [CrossRef]

20.Lillie, W. (1955). An Introduction to Ethics (3 ed.). London: Routledge. Available at: [Link]

21.Lokuwaduge, C., \& De Silva, K. (2019). Impact of corporate social responsibility practices on employee commitment. Social Responsibility Journal, Ahead-of-print. [Google Scholar] [CrossRef]

22.Mladenovic, R., Martinov-Bennie, N., \& Bell, A. (2019). Business students' insights into their development of ethical decision-making. Journal of Business Ethics, 155(1), 275-287. [Google Scholar] [CrossRef]

23.'Connor, G., Nejad, M., \& Estelami, H. (2020). Exploring Antecedents Of Unethical Business Decisions. American Journal of Business Education (AJBE), 13(2), 27-40. [Google Scholar]

24.Rajablu, M., Hamdi, S., \& Govindan, M. (2017). Managing for stakeholders: introducing stakeholder metrics-integrated model to lead project ethics and success. International Journal of Projects Organisation and Management, 9(1), 31-56. [Google Scholar] [CrossRef]

25.Rossi, M., Festa, G., Chouaibi, S., \& Fait, M. (2021). The effects of business ethics and corporate social responsibility on intellectual capital voluntary disclosure. Journal of Intellectual Capital, 22(7), 1-23. [Google Scholar] [CrossRef]

26.Toma, S.-G. (2006). From quality to the corporate social responsibility. Amfiteatru Economic, X(23), 80-85. [Google Scholar]

27.Toma, S.-G. (2008). Social responsibility and corporate citizenship in 21 st century. Amfiteatru Economic, VIII(20), 145-149. [Google Scholar] 
28.Toma, S.-G., Burcea, M., \& Papuc, R. (2011a). The social responsibility of organizations in times of crisis: The case of Toyota Motor Company. Ovidius University Annals- Economic Sciences Series, 11(2), 1274-1278. [Google Scholar]

29.Toma, S.-G., Stanciu, C., \& Irimia, E. (2011b). Landmarks in the evolution of social responsibility of organizations in the twentieth century. Proceedings of the 5th International Scientific Session Challenges of the Knowledge Society. Bucharest: PRO Universitaria. 1352-1360. Available at: [Link]

30.Toma, S.-G. \& Hudea, O.S. (2012). Corporate social responsibility, a key element of today's business organizations. The case of airline industry. Calitatea - acces la succes, 13(S3), 479-486. [Google Scholar]

31.Toma, S.-G. \& Marinescu, P. (2012). Business models based on corporate social responsibility: The case of global pharmaceutical companies. Ovidius University Annals- Economic Sciences Series, 12(1), 1221-1225. [Google Scholar]

32.Toma, S.G. (2013). Enterprise economy. Bucharest: University of Bucharest Publishing House. Available at: [Link]

33.van Luijk, H. (1997). Business ethics in Western and Northern Europe: A search for effective alliances. Journal of Business Ethics, 16(4), 1579-1587. [Google Scholar]

34.Voiculescu, N., \& Neagu, I.A. (2016). The social responsibility of enterprises. From concept to standardization. Bucharest: Academic Publishing House. Available at: [Link]

35.Zainea, L.N., Toma, S.-G., Grădinaru, C., \& Catană, Ș. (2020). Social entrepreneurship, a key driver to improve the quality of life: The case of TOMS Company. Business Ethics and Leadership, 4(3), 65-72. [Google Scholar] [CrossRef] 